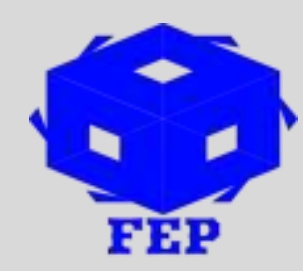

\title{
DEMOCRATIC SUSTAINABILITY AND CONFLICT RESILIENCE IN GHANA'S DEMOCRATIC SYSTEM
}

\author{
Halidu Musah ${ }^{1}$
}

${ }^{1,}$ Lecturer in Peace, Conflict and Democratic Governance at the Department of Social, Political and Historical Studies, Faculty of Integrated Development Studies, University for Development Studies, Wa Campus, Ghana.

*Corresponding Author: Halidu Musah

Corresponding Author Email: tkhalid2001@yahoo.com

Article Received: 11-04-19 Accepted: 29-04-19 Published: 05-05-19

Licensing Details: Author retains the right of this article. The article is distributed under the terms of the Creative Commons Attribution-NonCommercial 4.0 Licence (http://www.creativecommons.org/licences/by-nc/4.0/) which permits non-commercial use, reproduction and distribution of the work without further permission provided the original work is attributed as specified on the Journal open access page.

\section{ABSTRACT}

Ghana could be described as an island of peace in an ocean of conflicts. This is because most of Ghana's West African neighbours have experienced (and some are still experiencing) various forms of national civil conflicts which have never occurred in Ghana. In the last three decades, the West Africa sub-region has been plagued with many intra-state conflicts. In Liberia, Sierra-Leone, Côte d'Ivoire and Mali, conflicts have escalated into full scale war, bringing with it numerous loss of lives, destruction of property and causing social despair for the citizenry. The peace of some countries like Senegal, Nigeria, Niger and recently Burkina Faso also continues to be threatened by different dissident groups and popular uprisings. While most of these countries' democracies remain fragile due to the conflicts within these states, Ghana remains one of few examples whose current democratic structures have stood the test of time for the last three decades. This study inquired into Ghana's conflict resistance capacities and its ability to continue to sustain its democracy as a country. Mixed methods approach was employed to select 132 community residents from 3 purposefully sampled conflict-prone communities in Ghana, and 5 key informants as well as 462 political party delegates for interviewing and data collection for the study.

The study found that the very nature of Ghana's internal conflicts with respect to their geographical limitations, the conflict parties involved as well as the issues at stake contribute to confine these internal conflicts within their areas of occurrence. In addition, some conscious social and institutional measures (put in place) in the Ghanaian democratic system help to promote peace and maintain order. Finally, majority of the respondents (63.6\%) were of the opinion that Ghana is unlikely to have a national civil war because its democratic 
institutions are effective. It was suggested that politicians should avoid interfering in local conflicts and increase coverage for peace education programmes and conflict intervention initiatives in the country, among others.

Keywords: Conflict, Politics, Ghana.

\section{INTRODUCTION}

Conflicts, as a social phenomenon is considered in many circles as a natural phenomenon that is part and parcel of every social, political and economic system, and in fact, needed for innovation and the development of societies. Nonetheless, violent conflicts in many parts of the world have led to loss of lives and property. In Africa, just like in many parts of the world, conflicts have led to the deterioration of social and economic conditions as well as to the many unstable political environments in most African countries. This situation has attracted the attention of many scholars (Bombande, 2007; Otite, 2000; Drucker-Brown, 1995; Konate, 2004; Tonah, 2007; Apter, 1972; Lijphart, 1977; Mbonjo, 2000; Coser 1964; Awedoba, 2009; Horowitz, 2000). Countries such as Rwanda (1994), Somalia (1991; 2009), Angola (1975-2002), Burundi (1972; 1993), Central African Republic (2004; 2012), Chad (1965 to present), Republic of Congo (1997), Democratic Republic of Congo (1996; 1998 to date) and more recently Liberia, Sierra Leone, Kenya, Mali, and la Côte d'Ivoire, are examples.

Ghana remains a peaceful democracy with alternating governments and political parties. It has successfully organised many free and fair elections and the results of these elections accepted nationally. Ghana is accorded the image of a peaceful and politically stable country on the world stage, and most especially in the West Africa region. Its contribution to the unity and peace of the West Africa region remains imminent and recognised. This is reflected in its past peace-building role in regional and global organisations such as the Economic Community of West African States (ECOWAS), the African Union (AU), and the United Nations (UN) making Ghana a popular venue for peace talks and accords, as well as other socio-economic and political negotiations for development and security. Ghana is one nation among the lot in West Africa that has, in its political history, never experienced any national violence or civil war, at least in its modern political history.

However, in spite of its accolade as a politically stable country, Ghana has experienced, and continues to experience a series of long-standing violent inter-ethnic, intra-ethnic and intercommunal conflicts. Some of these conflicts have often resulted in loss of lives and properties (Brukum, 1995; Tsikata and Seini, 2004; Bogner, 2000). These conflicts, though mostly do not have cross-regional or national spill-over effects, yet their direct costs to victims and affected communities as well as their indirect cost to the Ghanaian nation have become a source of great worry to all successive governments of the country.

A number of communities in Ghana have experienced violent conflicts of various types inter/intra ethnic conflicts, religious conflicts, political violence between adherents of various political parties, industrial disputes between workers and employers such as strikes, withdrawal of partial services and demonstrations by doctors, teachers, lecturers and other industrial workers as in early 2013, and sports violence between supporters of opposing football teams. The most frequent, and by far the most destructive ones, are the intra-ethnic and inter-ethnic conflicts that usually occur over succession to traditional political offices or 
land boundary disputes (Brukum, 1999). We present below in Figure 1 a map of Ghana with some major conflict spots in the country.

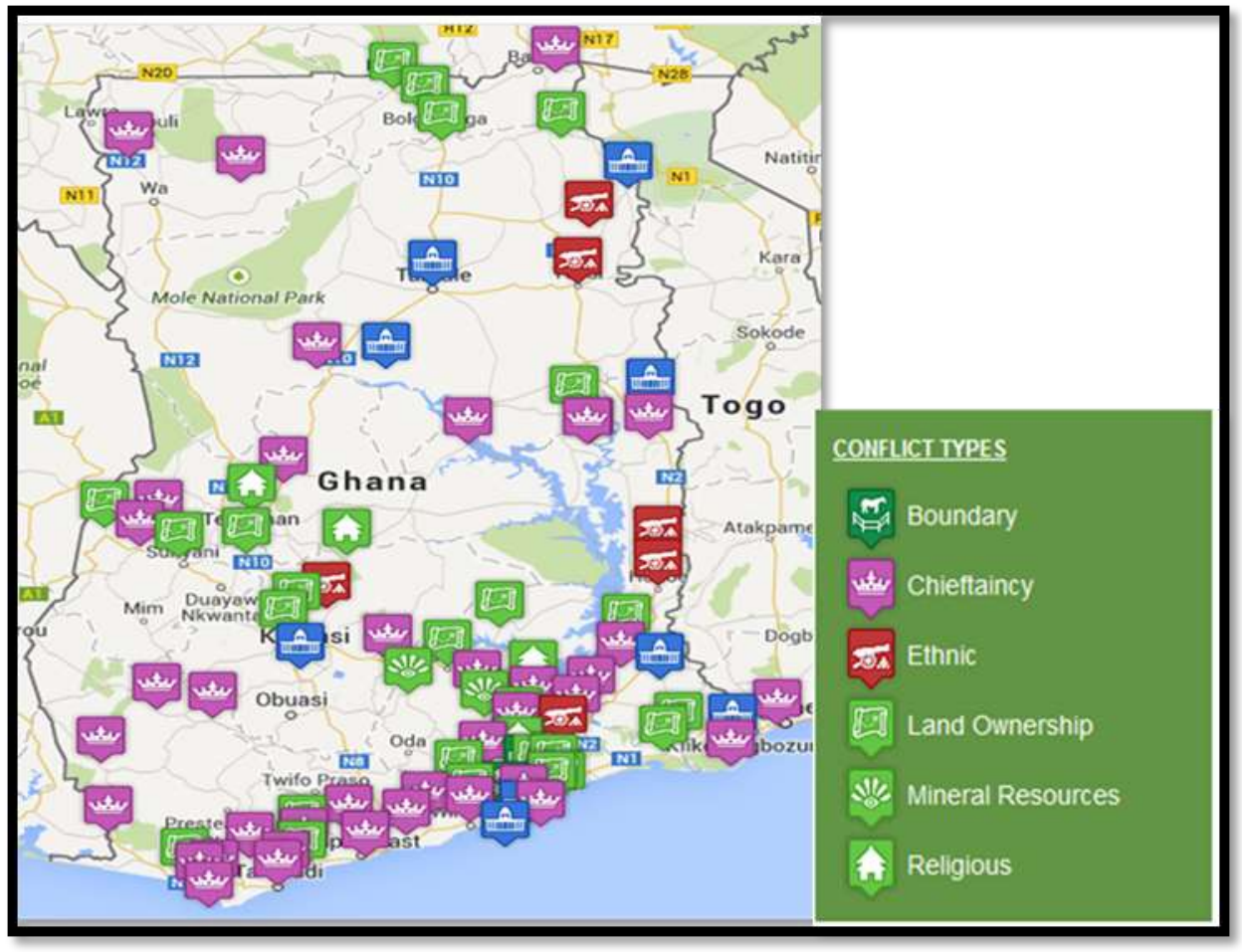

Figure 1:Ghana Map with Conflict Zones

Source: UNDP-National Peace Council Interactive Conflict Map of Ghana

Ethnic conflicts in Ghana have been very destructive in terms of their cost on human lives and property. Between February 1994 and March 1996, the Konkomba versus Nanumba/Dagomba conflict, which has come to be known as the 'Guinea Fowl War' claimed more than 2,000 human lives, and an estimated 178,000 people were displaced, 18,900 farm animals were lost (either stolen, killed or got lost), 144 farming villages destroyed and thousands of acres of farmlands as well as millions of dollars' worth of public and private property were destroyed (Fred-Mensah, 1999: 953 ; Brukum, 2007: 99 \& 112 ; Tonah, 2007:4 ). Conflict regulation forms an integral part of government expenditure in the country. For example, as of December 2009, estimates indicate that over 700000 USD was spent yearly on internal conflicts and conflict management in the three regions of Northern Ghana alone.

Whilst these violent internal conflicts paint a gloomy picture about conflicts in Ghana, the situation is unlike in other West African countries (such as Nigeria, Liberia, la Côte d'Ivoire and Sierra Leone among others) where internal differences and communal violence have led to nationwide civil wars. The internal conflicts experienced in Ghana have never degenerated into a national civil war. Nonetheless, many of these conflicts have been widely reported by the media and their impacts have been greatly felt by the citizenry (Tsikata and Seini, 2004; Ghanaian Times (GT) 2/9/97; GT 23/4/01; Awedoba, 2010; BBC, 18/01/08). What accounts for Ghana's ability to withstand these many internal conflicts and prevents them from escalating into violent nationwide conflicts remains unexplained. There should be an explanation to the Ghanaian case using an empirical study of this nature. 


\section{METHODOLOGY}

The research uses multiple sources of data and data collection strategies to enable us use diverse sources of information for the research. Primarily, this research touches both sociology and political science on its conflict dynamics and democratic stability perspectives respectively. With this diversity in mind, we used mixed methods approach, thereby combining both qualitative and quantitative strategies as and when appropriate.

The concurrent mixed methods procedure enabled us to make use of existing secondary data and field data that are both qualitative and quantitative in nature. This equally permitted the researcher to employ both qualitative and quantitative data collection tools successfully to help us get information needed for the study.

\section{Sampling Technique}

Sampling was done at two main levels, namely at the institutional level and at the community level. A combination of purposeful and accidental sampling techniques were adopted in the study. Purposeful sampling was adopted to select communities and institutions from which data was collected. These included three (3) conflict communities that were selected due to their conflict characteristics; five (5) institutions whose work is related to conflict and conflict resolution in Ghana; and two (2) political parties that have each won elections and ruled the country at different times since the onset of the 1992 Fourth $\left(4^{\text {th }}\right)$ Republican Constitution.

At the institutional level, purposeful sampling technique was used to select the National Peace Council, the Ghana Christian Council, the Ghana Muslim Council, the Electoral Commission of Ghana, and the UNDP that chartered the course for the drawing up of the Ghana Peace Architecture in 2010. An official each from these institutions were purposively selected and in this study constituted the key informants.

At the community level, the research targeted community residents of the three purposefully selected study areas, namely Tamale Metropolis (including current Sagnarigu), Yendi and Bunkpurugu-Yunyuo. Within the communities, the selection criteria was accidental. Information and knowledge of conflicts in the community are randomly distributed. This is because conflicts, when they explode, as they frequently do in our study communities, become public knowledge and affect all individuals in the community at various levels of intensity. This justifies the choice of willing and able residents of each conflict area for data collection. Respondents were selected based on their availability and readiness to accept to be interviewed. In Yendi and Bunkpurugu where geographical settlement patterns and perceptions of belonging were significantly discernible, we took samples in the two different settlement patterns of each conflict. For example, targeting 25 individuals from the Abudus side and 25 from the Andanis side in Yendi. In Bunkpurugu-Yunyuo, same was done for the Bunkpurugu and Yunyuo communities of the Bunkpurugu-Yunyuo District. In Tamale, there was no zoning of the community. Not more than two persons were interviewed from the same house. Respondents were interviewed using a questionnaire constructed around the main theme of the research.

\section{Sample Size}

Overall, 132 community respondents, 405 political party delegates and executives from the two main political parties in Ghana (NDC and NPP) and 5 key informants constituted the final sample size of 542 for the study. Table 1 below portrays the three categories of respondents sampled for data collection. 


\begin{tabular}{|c|c|c|c|c|}
\hline \multicolumn{5}{|c|}{ Table 1: Sampling Techniques and Sample Size } \\
\hline $\begin{array}{c}\text { Serial } \\
\text { No. }\end{array}$ & Category of Respondent & $\begin{array}{c}\text { No. of } \\
\text { Respondents } \\
\text { Interviewed }\end{array}$ & $\begin{array}{c}\text { Group } \\
\text { (Population)/Institut } \\
\text { ion Determination } \\
\text { Technique } \\
\end{array}$ & $\begin{array}{c}\text { Individual Unit } \\
\text { Sampling } \\
\text { Technique }\end{array}$ \\
\hline 1 & Community Respondents & 132 & Purposeful sampling & $\begin{array}{l}\text { Accidental } \\
\text { sampling }\end{array}$ \\
\hline 2 & Political Party Delegates & 405 & Purposeful sampling & $\begin{array}{l}\text { Accidental } \\
\text { sampling }\end{array}$ \\
\hline 3 & $\begin{array}{l}\text { Key Informants } \\
\text { (Institutional } \\
\text { Representatives) }\end{array}$ & 5 & Purposeful sampling & $\begin{array}{l}\text { Purposeful } \\
\text { sampling }\end{array}$ \\
\hline & Total & 542 & & \\
\hline
\end{tabular}

Source: Researcher's construct, 2018.

\section{Data Collection Methods, Techniques and Sources}

The study made use of both primary and secondary sources for the study. Primary data was collected at three levels. From community residents, political party delegates, and key informants from selected institutions.

The first level of data was collected through key informant interviews with the 5 key informants from the five institutions using an interview guide and a sound recorder to record the interview with the permission of the interviewees. These recordings were later transcribed during the data analysis for incorporation into the field results.

At the community level data were collected through structured questionnaire administered to respondents sampled from three known conflict-prone Metropolis, Municipality and District of the Northern region of Ghana

At the level of delegates, data were collected through face-to-face interview or questionnaire administration.

Apart from the primary data, the research also relied to a large extent on existing secondary data, historical and archival literature that are mostly narrative, in nature and analysis, to enable us make meaning into current events based on past ones, and how they influence certain variables and elements of our research and its core objectives.

\section{Data Analysis}

All the field data collected with questionnaires were managed by first pre-coding, editing, coding, and entering into a Statistical Package for Social Sciences (SPSS) software developed and owned by IBM Computer Systems. Data gathered with the aid of audio recording device were transcribed and carefully edited so as to maintain the original meaning or intention (information) given by the respondents. Specific results were run from the data and used to help answer specific questions raised in the objectives. These were presented in the form of tables, graphs, and charts as may be appropriate. In the data presentation, the community respondents' data was used as the major data source but complemented by data sets and information from the delegates and the key informants where necessary. Qualitative data were, however, analysed descriptively around the themes of the study. Both quantitative and qualitative data were woven together so as to develop a comprehensive and coherent picture about the problem that mooted the study.

\section{Theoretical Considerations}


The study employed the theory of consociational democracy as a guide to investigate the factors that account for the relatively peaceful democratic dispensation in Ghana for the past 25 years. The theory envisages that it is difficult for a country with multiethnic and plural social groups to establish, sustain and consolidate democratic governance systems unless that country follows certain prescriptions recommended by the theory. If such prescriptions are not followed, then the country will be plunged into conflict leading to its inability to establish a consensual working democracy.

By application in this study, we discuss consociational democracy with reference to Ghana as a plural society with a democratic system of governance despite its numerous internal conflicts, using consociationalism as a basis of analysis to determine the factors accounting for the stability of Ghana's democracy. The focus here is to determine the extent to which Ghana's democratic stability is accounted for or not by consociational arrangements.

Consociational democracy was first mentioned in Gabriel A. Almond's 1956 typology of democracies. Later, Arendt Lijphart ${ }^{1}$ elaborated more on the theory of consociationalsim agreeing with Almond on the vulnerability to instability in culturally heterogeneous societies that are 'divided by mutually reinforcing cleavages'. At first, Lijphart used the word 'politics of accommodation', but writing later in a 1968 World Politics article titled "Consociational Democracy", he employed the term "consociationalism"2. Historically, the term derives from Althusius' 1603 article in Politica Methodice Digesta, entitled "Concept of Consociatio". While Lijphart refers to Lewis as the intellectual originator of the theory of consociationalism, ${ }^{3}$ most literature on consociationalism refers to Lijphart as "the most productive and imaginative author" ${ }^{\prime 4}$ or the major contributor to the theory of consociational democracy and has been given much credit for its theoretical development.

Indeed, the importance of Lijphart's development of consociational theory is because the theory suggests to provide a concrete solution to the scepticism regarding the attainment of stable democracy in divided societies ${ }^{5}$. Halpern writes:

${ }^{1}$ Lijphart, Arendt (1968b). 'Typologies of democratic systems'. Comparative Political Systems Vol. 1,

No. 1, pp. 3-44.

${ }^{2}$ Lijphart, Arendt (1969). “Consociational Democracy”. World Politics (October), Vol. 21, No. 1

Pp-207-25. USA: Princeton University Press.

${ }^{3}$ Opcit

${ }^{4}$ Van Shendelen M. P. C .M (1984). 'The views of Arendt Lijphart and collected criticisms. In Van Schendelen, ed. Acta Politica Vol. 19, No. 1 [Consociationalism, pillarisation, \& conflict management in the Low Countries], (January), pp. 19-55. Amsterdam: U itgeverij Boom

${ }^{5}$ Halpern, Sue M. (1984), Consociational democracy and the dangers of politics as science. Doctoral Study. Oxford: University of Oxford. 
"...In the twentieth century, the prevalence of subcultural conflicts based upon race, language, religion, and ethnicity have rendered this scepticism [the dangers that subcultural differences pose for democracy] commonplace ( ...) the possibility of maintaining stable democracy in a sub-culturally fragmented state appeared to political theorists to be remote at best. For this reason alone, the publication of Arendt Lijphart's theory of consociational democracy might have attracted attention: unlike its pessimistic predecessors, this theory purports to demonstrate how stable democracy can be maintained in divided states ",

The above quotation reinforces our use of this theory believing that it was postulated as a strategy for addressing problems in culturally plural societies like Ghana to be able to institute, maintain and consolidate democratic governance.

A number of principles underlie the theory of consociationalism. In its formulation, a plural and multiethnic society can only establish and sustain democracy if these principles are adhered to. ${ }^{7}$ They comprise:

1. Grand coalition (executive power-sharing);

2. Group/segmental autonomy;

3. Proportionality; and

4. Mutual/Minority Veto.

According to Lijphart, executive power sharing entails the formation of a government made up of a grand coalition of the political leaders of all significant segments of the divided society. Lijphart differentiates this from the principle of majority rule and large opposition. ${ }^{8}$ In Ghana's democratic system, executive power is concentrated in a single president elected on the basis of a multiparty elections. The Presidential candidate of the party that wins becomes the executive head of the nation and government in power. However, the constitution enjoins all political parties to be constituted with a nation-wide membership without identification with any segment of society; not with any ethnic, religious, or regional character.

The second principle of consociationalism is to create a Segmental or community autonomy which entails the delegation from central government of high degree of autonomy to the segments of the plural society to enable as much autonomy in decision-making as possible to these separate segments. By extension, decision-making on all issues of common interest must be arrived at jointly by the representatives of the main segments. However, when it

\footnotetext{
${ }^{6}$ Ibid, 1.

7 Lijphart, Arendt (2000b). 'The wave of power-sharing democracy'. Cited in Noura, Assaf (2004). Consociational theory and democratic stability: A re-examination Case Study: Lebanon”. Unpublished Study, University of Warwick, Department of Politics and International Studies

${ }^{8}$ Lijphart, A. (1977). Politics in Plural Societies: A Comparative Exploration. New Haven and London Yale University Press. P.25.
} 
comes to other issues that are not of common national interests, decision-making should be left to each segment to determine what is good for the interest of that segment. Segmental autonomy in Ghana may be perceived in terms of Ghana's decentralised governance system where there exists both devolution and decentralisation.

The third principle of consociational democracy is proportionality. The principle of proportionality is closely linked to that of grand coalition. Proportionality is to ensure fairness in segmental representation in civil service appointments and allocation of scarce financial resources in the country ${ }^{9}$. This is to ensure the removal of "a large number of potentially divisive problems from the decision-making process and thus lightens the burdens of consociational government." ${ }^{10}$ Proportionality also has a positive influence on the process and outcome of decision-making, such that “...a roughly proportional distribution of influence in policy problems can usually only be assured if the decision is bargained over with the participation of all groups". ${ }^{11}$ This, of course, enables each group to influence decision and policy process in correspondence with the weight of its representation of that segment in the country, thereby ensuring fairness.

The fourth component is mutual or minority veto. Mutual veto is the constitutional provision of veto rights to minority groups in the consociation as a means of protecting their rights in the case of majority votes to determine decision that the minority may find very vital to their interests and very existence. The minority will, under this principle, be able to block a decision they find inimical to them and lobby for change. This will "give each segment a complete guarantee of political protection" " on vital issues and constitutional change. Mutual veto guarantees to each segment that it will not be outvoted by the majority when its vital interests are at stake.

\section{RESULTS}

\section{Why Ghana has never experienced a nationwide violent conflict}

Respondents were asked to tell why, in their view, the many conflicts dotted around Ghana have never gone violent nationwide. The responses obtained from our community sample cohort, as displayed on Table 2 below, indicate that 40 respondents $(30.3 \%)$ said Ghana has never experienced a nationwide violent conflict because most conflicts are on tribal and chieftaincy issues (small communities, regions or tribes). Another 28 respondents $(21.2 \%)$ said it is because the Justice system in Ghana works well, whilst some 14 respondents each (10.6\% each) said it is because the security services such as the police and the military are

\footnotetext{
${ }^{9}$ Ibid, pp.38-41

${ }^{10}$ Ibid, p.39

${ }^{11}$ Jurg Steiner (1971). "The Principles of Majority and Proportionality." British Journal of Political Science, 1, No. 1 (January 1971)65. Cited in Lijphart A. (1977). Democracy in Plural Societies: A Comparative Exploration. New Haven and London Yale University Press.
}

12 Lijphart, A. (1977). Politics in Plural Societies: A Comparative Exploration. New Haven and London Yale University Press. p.37. 
doing a good job and Ghanaians are peace loving people respectively. Some 9 respondents $(6.8 \%)$ attributed it to the multi-ethnic nature of Ghana. Another 8 respondents $(6.1 \%)$ attributed Ghana's peaceful democracy to the availability of peace promoting networks/organisations and institutions who are usually involved in conflict resolution, whilst 6 respondents $(4.5 \%)$ believe that the state puts in place measures to prevent conflicts. Some 4 others (3.0\%) said because there exists cross-cutting ties among the people in Ghana. Two (2) respondents each (1.5\% each) attributed Ghana's peace to the promotion of peace by the Ghanaian media; most Ghanaians have seen and are aware of the negative consequences of conflicts in other countries; and because of respect for democracy respectively.

\section{Table 2: Reasons why Conflicts in Ghana do not lead to Nationwide Violent Wars}

\section{Why has Ghana never experienced a nationwide violent conflict?}

\begin{tabular}{|c|c|c|}
\hline Reasons & Frequency & Percentage $(\%)$ \\
\hline $\begin{array}{l}\text { Most conflicts are on tribal \& chieftaincy issues (small communities, } \\
\text { regions or tribes) not nation-wide }\end{array}$ & 40 & 30.3 \\
\hline Because the Justice system in Ghana Works & 28 & 21.2 \\
\hline $\begin{array}{l}\text { Because the security services such as the police and the military are } \\
\text { doing a good job }\end{array}$ & 14 & 10.6 \\
\hline Ghanaians are peace-loving & 14 & 10.6 \\
\hline Because of the multi-ethnic nature of Ghana & 9 & 6.8 \\
\hline $\begin{array}{l}\text { Availability of peace promoting network/organisation \& institutions } \\
\text { usually involved in the conflict resolution }\end{array}$ & 8 & 6.1 \\
\hline Because the state puts in place measures to prevent conflicts & 6 & 4.5 \\
\hline Because there exist cross-cutting cleavages in Ghana & 4 & 3 \\
\hline The Ghanaian media promote peace & 2 & 1.5 \\
\hline $\begin{array}{l}\text { Most Ghanaians see and are aware of the negative consequences of } \\
\text { conflicts in other countries }\end{array}$ & 2 & 1.5 \\
\hline Because of respect for democracy & 2 & 1.5 \\
\hline $\begin{array}{l}\text { Because there is food security in Ghana so there are no hungry persons } \\
\text { who will go to create any problem for conflict to occur }\end{array}$ & 1 & 0.8 \\
\hline Because of the intervention of religious bodies & 1 & 0.8 \\
\hline God protects Ghana against nationwide conflicts & 1 & 0.8 \\
\hline Total & 132 & 100 \\
\hline
\end{tabular}

One (1) respondent each ( $0.8 \%$ each) said Ghana has never experienced a nationwide violent war because there is food security in Ghana so no one can influence any Ghanaian to go and create any problem for conflict to occur; Because of the intervention of religious bodies; and God protects Ghana against nationwide conflicts.

The results here above on Table 2 emphasize the fact that when conflicts are dispersed to the local level, it saves the wider national level from conflicts (Horowitz, 2000). Even though Ghana is not a federal state as Horowitz espoused on multiethnic polities, the ethnic and territorial (geographical) boundaries within which most of the conflicts occur in Ghana help to naturally circumscribe their effects to remain within the boundaries and populations among 
whom the conflicts occur only. This makes it impossible for conflicts to spread to the whole population, since it is not everyone who may be interested or concerned with the issues that are at the core of the conflicts in question. Also, the national seat of government has never been contested in any violent conflict since January 1993 when the Fourth Republic was outdoored, even if contests by political parties for the Presidency have sometimes turned violent in some areas in the country, but these are usually between a few individuals or groups in given constituencies. These violent occurrences are, just like other conflicts in the country, isolated cases without a conscious nationwide mobilisation by opposing sides to engage in such conflicts (Tsikata and Seini, 2004).

In addition, the identification of the judicial system as one of the second most important contributory factors to Ghana's peaceful democracy is a further confirmation of citizens' positive perception of the judicial system as an institution that is functioning properly to serve the interests of the people as earlier affirmed by same community respondents in study five of this study. Another important factor is the identification of Ghanaians being peace-loving. So also is the perceived trust of respondents in the security services as contributing to the peaceful democratic order in the country. These are important features of every peaceful democracy (Diamond, 1999; 2003; 2017 ${ }^{13}$ ). Violent conflicts emanate principally from groups' and individuals' failure to understand and empathise with one another in times of disagreement and diversity of interests (Fisher, Ury and Patton, 1991) ${ }^{14}$. The ability to understand and tolerate one another across social divides is a critical ingredient for the survival and sustainability of democracy in a plural society (Lijphart, 1969; 1972; Horowitz, 2000). Peace-loving people exhibit positive attitude towards conflicts as opposed to violentloving people who exhibit negative behaviour in times of conflicts (Fisher, Ury \& Patton, 1991). The way and manner individuals and groups approach conflicts is capital to the determination of the course and product of conflicts. Conflicts are natural in every human society (Coser, 1956). The determination to find positive solutions to conflicts when they arise helps to reduce violence and keeps conflicts at levels that allow democracies to thrive without major shocks and truncations in the existence and functioning democratic institutions and systems. The lack of such determination in times of conflicts, however, renders a nation vulnerable to violent conflicts and risk of democratic recession. Going forward, it is important to know whether Ghana runs any risk of running into a nationwide violent conflict that citizens might see imminent in the near future.

\section{Risk of Nationwide Violent Conflict in Ghana}

Respondents were asked to tell if, in their view, Ghana runs the risk of a nationwide violent conflict in the near future as witnessed in Liberia, Sierra Leone and la Côte d'Ivoire among others. To this, 48 respondents, constituting 36.4\% answered "yes" while 84 respondents (63.6\%) said "no". Their responses are captured on Table 3 below.

13 Diamond, L. (2017). Democracy Only as Strong as Citizens' Support for It. SFGate. March 9, 2017. https://www.sfgate.com/opinion/article/Democracy-only-as-strong-as-citizens-support-10991552.php

${ }^{14}$ Fisher, R., Ury, W., \& Patton, B. (1991). Getting to yes: Negotiating agreement without giving in. 
Table 3: Possibility of Future Nationwide Violent Conflict in Ghana

\begin{tabular}{|c|c|c|}
\hline \multicolumn{2}{|c|}{ Does Ghana run the risk of a national conflict one day? } \\
\hline Responses & Frequency & Percent \\
\hline Yes & 48 & 36.4 \\
\hline No & 84 & 63.6 \\
\hline Total & & \\
\hline
\end{tabular}

Source: author's fieldwork, 2014/2015, Ghana

When asked to explain their responses (as on Table 3 above), those respondents who said Ghana runs the risk of a future nationwide conflict provided the following reasons for their answers as captured on Table 4 below. About 25\% of respondents (12) indicated that the behaviour of Ghanaian politicians and wrongful conduct of political activities are what could lead to such a conflict. Another $22.9 \%$ of them (11) said such a conflict will occur if the government fails to solve existing conflicts in the conflicting communities or zones. About $10.4 \%$ each (5 respondents each) also think that national elections can easily create national conflicts, and high corruption in the country can lead to a national violent conflict. Some 8.3\% (4 respondents) said there is too much injustice in the country, while $6.3 \%$ (3 respondents) said such a conflict will occur if the government is not proactive in dealing with political conflicts. About $4.2 \%$ of respondents each (2 respondents each) indicated that conflicts will occur because of disrespect for others; and people should be educated to avoid conflicts otherwise a cluster of conflicts can affect Ghana respectively. In all, an aggregate of 20 respondents $(41.7 \%)$ point to politic and political related reasons that constitute a danger to the Ghanaian democracy and are likely to cause nationwide conflicts in Ghana (as indicated in the pink-coloured cells of Table 4 below). This gives credence to politics and political manipulation identified earlier as one of the major causes of conflicts in Ghana in study 4 of this work, as well as in the works of Tsikata and Seini (2004), Odotei and Awedoba (2006), Ayee et al (2012) and Tonah (2012). 


\section{Table 4: Why Ghana Risks a Nationwide Violent Conflict}

\begin{tabular}{|c|c|c|}
\hline \multicolumn{3}{|l|}{ Explain your answer in 2 - YES } \\
\hline Reasons why Ghana Risks Violent War & Frequency & $\begin{array}{l}\text { Percentage } \\
(\%)\end{array}$ \\
\hline $\begin{array}{l}\text { The behaviour of politicians and wrongful conduct of political } \\
\text { activities can lead to a national conflict }\end{array}$ & 12 & 25.0 \\
\hline $\begin{array}{l}\text { If the government fails to solve the existing conflicts in the } \\
\text { conflict communities or zones }\end{array}$ & 11 & 22.9 \\
\hline Our national elections can easily create national conflicts & 5 & 10.4 \\
\hline Corruption always goes high in the country & 5 & 10.4 \\
\hline There is too much injustice in Ghana & 4 & 8.3 \\
\hline $\begin{array}{l}\text { If governments are not proactive in dealing with political } \\
\text { conflicts }\end{array}$ & 3 & 6.3 \\
\hline Because of disrespect for others & 2 & 4.2 \\
\hline $\begin{array}{l}\text { People should be educated to avoid conflicts otherwise a } \\
\text { cluster of conflicts can affect Ghana }\end{array}$ & 2 & 4.2 \\
\hline $\begin{array}{l}\text { Looking at the nature of chieftaincy issues, if not managed } \\
\text { well it will lead to conflicts }\end{array}$ & 1 & 2.1 \\
\hline $\begin{array}{l}\text { The trends of ethnic dominance by the Akans may set other } \\
\text { ethnic groups against them }\end{array}$ & 1 & 2.1 \\
\hline $\begin{array}{l}\text { Because of the culture of impunity with which many do act } \\
\text { during conflicts }\end{array}$ & 1 & 2.1 \\
\hline $\begin{array}{l}\text { It is obvious that Ghana has become a bipartisan state } \\
\text { (NDC/NPP) if not managed well there could be a clash } \\
\text { between NDC \&NPP }\end{array}$ & 1 & 2.1 \\
\hline Total & 48 & 100 \\
\hline
\end{tabular}

\section{Source: Author's fieldwork, 2014/2015, Ghana.}

In addition, another, $2.1 \%$ each (1 respondent each) attributed it to the poor management of chieftaincy conflicts, ethnic dominance by the Akan ethnic group; the culture of impunity during and after conflicts, and that it is obvious that Ghana has become a bipartisan state (NDC/NPP) if not managed well there could be a clash between NDC and NPP supporters, respectively.

It is obvious that the respondents who believed Ghana runs the risk of a nationwide conflict (36.4\%) are far less than those who believe Ghana does not run that risk $(65.6 \%)$. The reasons given by the former's group of respondents are quite evident and present in the Ghanaian society. For example, politics, political elections and the meddling of politicians in local conflicts; the many unresolved conflicts in the country; and ethnicity issues are present features of conflicts in Ghana as identified in Study 4 under causes of conflicts in Ghana. In addition, Many other notable research works have also confirmed these factors as endangering the peace of Ghana's democracy (Tsikata and Seini, 2004; Adotei and Awedoba, 2006; Awedoba, 2009; Tonah, 2012; Wuaku Commission, 2002; Ayee, 2011; Lund, 2003, Anamzoya and Tonah, 2012).

Another notable variable that is overarching from these same respondents is the issue of corruption which was not much dominant (in respect of the statistics) but not negligible under the causes of conflicts. The issue of corruption in Ghana, has become a topical national issue for some time now, and has constantly appeared in the manifestoes of all political parties as a 
problem that needs attention from governments if Ghana's democracy is to grow positively. The two dominant political parties have constantly used it against each other to prove how much each of them is either dedicated to developing Ghana or running the country down. Since the emergence and prominence of investigative journalism in Ghana, which has led to the unearthing of prominent corruption cases, especially in the last 8 years, citizens have measured and assessed governments' performance by how much that government has fought corruption or allowed it to grow in Ghana. Examples include Anas Armeyaw Anas pieces on corruption in the police, in the electricity company of Ghana, the judiciary, and recently in the Ghana football Association/Confederation of African football ("No. 12"); as well as Manesseh Azure Awini's corruption exposures in the Ghana Youth Employment and Entrepreneurial Development Agency (GYEEDA); the National Service Secretary (NSS) and Ministry of Local Government with Zoomlion Ghana Limited. Massive confusion rocked the Ghanaian judicial system in 2016 after the release of "enemies of the state", leading to the creation of a national investigative Judicial Committee and the subsequent dismissal and resignation of many judges.

During the 2016 elections, the New Patriotic Party (NPP) devoted much of its time and resources to analysing contracts awarded by the National Democratic Congress (NDC) government and exposing so much fraud within the former government, leading to Ghanaians voting massively against the NDC government. These are indications and proof that corruption has become a real issue for the survival of the Ghanaian democracy just like any other established democracy.

For the 84 respondents who said Ghana does not run the risk of any violent national conflicts, 10 different reasons were given for their answers. These are shown on Table 5 below. Among these, the peace-loving nature of Ghanaian was evoked once again, but this time it occupies the highest position with 22 respondents, representing 26.2\% who said Ghanaians are peaceloving people that always work for peace in the country. The second reason was the natural circumscription (ethnic, regional and geographical effect) of internal conflicts in Ghana. To this, $21.4 \%$ of community respondents (18 respondents) said Ghana does not run the risk of any violent national conflict because it is not all the regions that are involved in such conflicts, whilst $15.5 \%$ (13 respondents) attributed their answer to the strong nature of Ghana's democracy. They said Ghana has a strong democracy that embraces diversity and will protect the peace of the nation. Another 14.3\% (12 respondents) attributed it to the religious nature of the majority of Ghanaian population indicating that the majority of the people in Ghana are God-fearing and prayerful so God will not permit a conflict in Ghana, $9.5 \%$ (8 respondents) believed the security forces and law systems intervene appropriately in conflicts to ensure peace in Ghana always. The rest said Ghanaians are law-abiding (4 respondents, representing 4.8\%); peace is being preached day-in-day out in Ghana (3 respondents, representing 3.6\%); and 2 respondents, representing $2.4 \%$ said they did not know and could not explain their answer but they believed that Ghana would not fall to any nationwide

conflict. 


\section{Table 5: Reasons why Ghana would not Experience a Nationwide Violent Conflict}

Why Ghana does not run the risk of a nationwide Violent Conflict

\begin{tabular}{|c|c|c|}
\hline Reasons & Frequency & $\begin{array}{l}\text { Percentage } \\
(\%)\end{array}$ \\
\hline $\begin{array}{l}\text { Ghanaians are peace-loving people that always work for peace in } \\
\text { the country }\end{array}$ & 22 & 26.2 \\
\hline Because it is not all the regions that are involved in such conflicts & 18 & 21.4 \\
\hline $\begin{array}{l}\text { Because Ghana has a strong democracy that embraces diversity } \\
\text { and will protect the peace of the nation }\end{array}$ & 13 & 15.5 \\
\hline $\begin{array}{l}\text { Majority of the people in Ghana are God-fearing and prayerful so } \\
\text { god will not let there be a conflict in Ghana }\end{array}$ & 12 & 14.3 \\
\hline $\begin{array}{l}\text { Because the security forces and law systems intervene } \\
\text { appropriately }\end{array}$ & 8 & 9.5 \\
\hline Ghanaians are law abiding people & 4 & 4.8 \\
\hline Because day-in-day-out, peace is being preached & 3 & 3.6 \\
\hline Can't tell / can't explain / don't know & 2 & 2.4 \\
\hline Because problems are easily resolved when they occur & 1 & 1.2 \\
\hline $\begin{array}{l}\text { Ghanaians are very much aware that politicians don't speak the } \\
\text { truth }\end{array}$ & 1 & 1.2 \\
\hline Total & 84 & 100 \\
\hline
\end{tabular}

Source: Author's fieldwork, 2014/2015, Ghana.

Some relevant issues emanate from these results. The importance of attitude to conflict is highlighted here as a prime factor for the peaceful democratic order in Ghana. Attitude has been identified by many practitioners and scholars as that fundamental determinant of the outcome of conflicts in society (Galtung, $1969^{15}$; Wallensteen, $2007^{16}$ ). This conceptualisation of conflicts is supported by many other writers (Zeytoonian, 2014 ${ }^{17}$; Bell, 2002 ${ }^{18}$; Robin, 2002 ${ }^{19}$; Thakore, $2013^{20}$; Kinsella and Rousseau, 2009 $9^{21}$; Bercovitch, 1983 $3^{22}$; Verma, $1998^{23}$; Yousef et al $2010^{24}$ ).

${ }^{15}$ Galtung, J. (1969). Violence, Peace, and Peace Research. Journal of Peace Research, Vol. 6, No. 3 (1969), pp. 167-191. Sage Publications, Ltd.

16 Wallensteen, P. (2007). Understanding Conflict Resolution: War, Peace and the Global System. SAGE Publications, 2007

${ }^{17}$ Zeytoonian, M (2014). Lessons from Jerusalem; Part I: what attitude do we bring to our conflicts?, Dispute Resolution Council, LLC, September 18, 2014

${ }^{18}$ Bell, A. (2002). Six Ways to Resolve Workplace Conflicts. San Francisco, CA: University of San Francisco.

19 Robin, D. (2002). When to engage, when not to engage. A Daniel Robin and Associates website. http://www.abetterworkplace.com

${ }^{20}$ Thakore, D. (2013). Conflict and Conflict Management. IOSR Journal of Business and Management (IOSR-JBM) e-ISSN: 2278-487X. Volume 8, Issue 6 (Mar. - Apr. 2013), PP 07-16. www.iosrjournals.org 
Ghanaians being perceived as peace-loving will definitely assist in how conflicts in the Ghanaian political system are managed so as to reduce the possibility of them becoming violent and spreading beyond bounds.

Another index of interest on Table 5 is the localisation of conflicts (Harowitz, 2000) where issues in local conflicts remain of interest only to members of the local community and do not attract the interests of the various communities across the nation. This notwithstanding, there are instances in Ghana where conflicts are imported or exported from local conflict zones to cosmopolitan cities like Kumasi and Accra where residents across the conflict lines from conflict zones have migrated to. This is the case with the conflicts of Agbogbloshie in Accra where there are frequent bloody clashes between the Konkombas and Dagombas, a conflict believed to be the sequels of the 1994 Konkomba - Dagomba/Nanumba interethnic conflict that devastated much of the Northern Region of Ghana. The most recent of these conflicts was the one that occurred in April $2017^{25}$. The same is the case with the occasional clashes between the Abudus and Andanis in Alabar, a suburb of Kumasi, the capital of the Ashanti Region ${ }^{26}$. However, each time these conflicts erupt in the "diaspora", the security services, traditional authorities and their indigenes as well as other groups that are not directly linked to the conflict quickly intervene, and sometimes the traditional authorities threaten sacking them out of their land if they should disturb the peace of their host traditional areas. This approach always quickens the pace of lessening the violence when they occur, and it controls the spread of violence and belligerents' response to same.

Furthermore, respondents expressed confidence in the Ghanaian democratic system, recognizing its capacity to "embrace diversity" and thereby making it capable of "protect(ing) the peace of

${ }^{21}$ Kinsella, D. and Rousseau, D. L. (2009). Democracy and Conflict Resolution. In Bercovitch, Kremenyuk, V. and Zartman, I. W. (2009). SAGE Handbook of Conflict Resolution. SAGE UK, 2009.

${ }^{22}$ Bercovitch, J. (1983). "Conflict and Conflict Management in Organizations: A Framework for Analysis", The Asian Journal of Public Administration, 5(2), December, 1983.

${ }^{23}$ Verma, V. K. (1998). Conflict Management. In Pinto, J. (Ed) (1998). The Project Management Institute Project Management Handbook 1998 ISBN 0-7879-4013-5.

${ }^{24}$ Yousef, S., Hipel, K. W., \& Hegazy, T. (2010). Attitude-based strategic negotiation for conflict management in construction projects. Paper presented at PMI Research Conference: Defining the Future of Project Management, Washington, DC. Newtown Square, PA: Project Management Institute. Found online at https://www.pmi.org/learning/library/attitude-based-strategic-negotiation-conflict-6476

${ }^{25}$ Citifmonline. "Konkombas, Dagombas clash again at Agbogbloshie; many injured”. Tuesday, April 11, 2017 4:10 pm http://citifmonline.com/2017/04/11/konkombas-dagombas-clash-again-at-agbogbloshie-many-injured/

${ }^{26}$ http://www.a1 radioonline.com/2017/08/17/tension-in-kumasi-as-abudus-andanis-clash-at-alabar/ 
the nation". Strong democratic institutions and the recognition and obedience of the rule of law by all facets of society is an important element for the success of democracies, especially in multiethnic and multicultural political systems (Diamond, 1999; Horowitz, 2000).

Among the key informants interviewed, all these three factors were identified as contributory factors to Ghana not having had any nationwide conflict. For example, one key informant noted: "Ghana is only lucky to have escaped violent nationwide conflicts since independence, but also it is because of the nature of the conflicts. We don't go fighting and shooting anyhow. So you see that people fight themselves within their communities, and this will not bring other regions to join any of the fighting parties; what for? It doesn't concern them. Even if you kill yourselves, people in other communities and regions will at best insult you, they won't just pick arms and decide to join you for a conflict that does not concern them," (Key Informant, 2015).

Another key informant remarked:

"Most people in Ghana are religious and peace-loving. We are not the very violent type of people. Some cultures are violent from history, but modernization and the need for law and order that comes with modern democracy makes it difficult for such people to behave violently. The law will deal with you. So people are careful. The democratic system is in itself a guide and pressure point that regulates our conducts" (Key informant, 2015).

On the possibility of a future nationwide conflict that may derail the country's democratic system, one key informant said:

"Conflicts in democracies like Ghana are normal. We are mixed. Many ethnic groups and everyone wants something from the system. Why won't we have conflicts? As for the future...you know they say it's unknown. Our political leaders must be careful. They have to bring everyone on board. You can't satisfy everyone, but Ghanaians are discerning. We can see if things are being done right or not. So when we do things right, our future is bright. If we don't, we may have problems. But all in all, I think there is more optimism than pessimism." (Key informant, 2015)

All these point to the fact that there are a lot of existing factors that Ghana can capitalize on to enhance its peaceful democratic development and consolidation, but for how long can a country with such features continue to resist violence when day-in-day-out conditions exist for such violence? The next point assesses Ghana's capacity to resist nationwide violent conflicts.

\section{Capacity to Resist Large Scale Violent Conflict}

To further examine Ghana's conflict resistance capacity, the study inquired into respondents' perception of Ghana's capacity to resist large scale conflicts. From Table 6 below, 69 respondents $(52.3 \%)$ out of the 132 community respondents indicated that Ghana had the capacity to resist large scale conflicts as a country, whilst 30 respondents $(22.7 \%)$ said Ghana did not have that capacity. Another 32 respondents (24.2\%) indicated that they did not know and could not tell if Ghana has that capacity or not, and 1 respondent $(0.8 \%)$ said it depends. The responses of our respondents to this question demonstrate the level of uncertainties associated with conflict prediction, and that in itself demonstrates a problem. The more certain a population is of its conflict situation, the more they trust the activities of other people and interpret same 
within the context of such trust. It is, however, understandable for people of conflict areas, as in the case of these respondents, to express uncertainties regarding conflict activity, because most of those conflicts are recurrent and it is always uncertain what happens the next moment.

Table 6: Ghana's Capacity to Resist Large Scale Conflict

\begin{tabular}{|l|l|l|}
\hline \multicolumn{2}{|c|}{ Can Ghana resist large scale nationwide war? } \\
\hline Responses & Frequency & $\begin{array}{l}\text { Percentage } \\
(\%)\end{array}$ \\
\hline Yes & 69 & 52.3 \\
\hline No & 30 & 22.7 \\
\hline don't know & 32 & 24.2 \\
\hline it depends & 1 & 0.8 \\
\hline Total & & $\mathbf{1 0 0}$ \\
\hline
\end{tabular}

Source: Author's fieldwork, 2014/2015, Ghana

Consequently, we asked respondents to explain the reasons for their answers as on Table 6 above. Their reasons are summarised on Table 7 below. Table 7 demonstrates that, among the 69 respondents, $(52.3 \%)$ who indicated that Ghana has the capacity to resist large scale conflicts, 23 of them (33.3\%) explained that Peace education and conflict sensitisation are effective in Ghana and the message is going down well with Ghanaians, whilst 10 respondents, representing $14.5 \%$ said Ghanaian security services are effective and we can count on them to prevent nationwide violent conflicts. In addition, 9 respondents (13.0\%), 7 respondents $(10.1 \%)$, and 5 respondents (7.2\%) each said Individuals, institutions and bodies have worked well in solving conflicts; Ghana needs peace and development; and God will not permit war in Ghana due to the religious nature of the people respectively.

Further, 4 respondents each (5.8\% each) said because there is unity and understanding in Ghana; and there is respect for rule of law in Ghana respectively. Some 3 respondents (4.3\%) said the majority of Ghanaians are not corrupt, and 2 respondents each said because of the multiethnic nature of Ghana, and don't know respectively. 
Table 7: Ghana's Capacity to Resist Large Scale War

\begin{tabular}{|c|c|c|}
\hline \multicolumn{3}{|l|}{ Capacity to Prevent violent national war } \\
\hline Responses & Frequency & Percent \\
\hline $\begin{array}{l}\text { Peace education and conflict sensitisation is effective in Ghana and the } \\
\text { message is going down well with Ghanaians }\end{array}$ & 23 & 33.3 \\
\hline $\begin{array}{l}\text { Because our security services are effective and we can count on them } \\
\text { to prevent nationwide violent conflicts }\end{array}$ & 10 & 14.5 \\
\hline $\begin{array}{l}\text { Individuals, institutions and bodies have worked well in solving } \\
\text { conflicts }\end{array}$ & 9 & 13.0 \\
\hline Ghana needs peace and development & 7 & 10.1 \\
\hline God will not permit war in Ghana due to our religious nature & 5 & 7.2 \\
\hline Because there is unity and understanding in Ghana & 4 & 5.8 \\
\hline There is respect for rule of law in Ghana & 4 & 5.8 \\
\hline Majority of Ghanaians are not corrupt & 3 & 4.3 \\
\hline Can't tell/no idea/don't know & 2 & 2.9 \\
\hline Because of the multi-ethnic nature of the country & 2 & 2.9 \\
\hline Total & 69 & 100 \\
\hline
\end{tabular}

Source: Author's fieldwork, 2014/2015, Ghana

For the respondents that answered "no" to Ghana's ability to resist a nationwide conflict, they were asked to explain their answer, and Table 8 below summarises their explanations. Among them, $26.7 \%$ of respondents (8) said Ghana does not have the capacity to resist nationwide violent war because politicians continue to meddle into local conflicts, and 23.3\% (7 respondents) said poverty is making people vulnerable to political manipulation into causing violence in society to the benefit of the politicians. Another $16.7 \%$ (5) said peace education does not reach a large number of Ghanaians especially in the villages, whilst $13.3 \%$ (4 respondents) indicated that Ghana has few security personnel, and some of them do not do their work well. Some $13.3 \%$ (4 respondents) also said there is too much tribalism in Ghana, whilst $6.7 \%$ (2 respondents) indicated that corruption has eaten into Ghanaian fabric and if not checked will cause a nationwide uprising against our leaders and bring down the democratic order in the country. 


\section{Table 8: Reasons why Ghana May not be able to Resist a Nationwide Violent Conflict}

\begin{tabular}{|c|c|c|}
\hline \multicolumn{3}{|c|}{ Why Ghana may not be able to resist a nationwide violent war } \\
\hline Responses & Frequency & $\begin{array}{l}\text { Percentage } \\
(\%)\end{array}$ \\
\hline Our politicians meddle into local conflicts & 8 & 26.7 \\
\hline Poverty is making people vulnerable to political manipulation & 7 & 23.3 \\
\hline $\begin{array}{l}\text { Peace Education does not reach a large number of Ghanaians, } \\
\text { especially in the villages }\end{array}$ & 5 & 16.7 \\
\hline $\begin{array}{l}\text { Ghana has few security personnel, and some of them do not do } \\
\text { their work well }\end{array}$ & 4 & 13.3 \\
\hline There is too much tribalism & 4 & 13.3 \\
\hline $\begin{array}{l}\text { Corruption has eaten into the Ghanaian fabric and if not } \\
\text { checked it will cause a nationwide uprising }\end{array}$ & 2 & 6.7 \\
\hline Total & 30 & 100 \\
\hline
\end{tabular}

Source: Author's fieldwork, 20142015, Ghana.

When the same question was posed to the key informants, this was what one of them said:

"One cannot say Ghana is insulated from any violent conflict. Every nation is prone to conflict unless you do things right. Especially in a multiethnic country like ours. Our leaders know we are prone to conflict. That is why we have the National Peace Council. It is meant to prevent violent conflicts, and resolve them wherever they occur. We should not think we are better than Liberia or Sierra Leone. They had also passed through peaceful times like Ghana before their conflicts erupted. So we cannot take our current peace for granted. We need to be conscious of this and activate the right political, social and cultural institutions to function properly to our advantage. Individual behaviour too is important. I am not compelled to slap you back if you slap me. I may report to the police instead of slapping you back. If the police pick you up, would you slap them? No. But if I slap you back we might fight and draw other people into the confrontation and before we realise it might grow to become an inter-family or even inter-ethnic conflict" (Key informant, 2014)

\section{Measures to increase Ghana's capacity to withstand or prevent large scale conflicts}

Based on the preceding results/data, respondents were asked to suggest measures that could help to increase Ghana's capacity to withstand or prevent large scale conflicts. Table 9 below presents a summary of their answers.

According to the responses, 33 respondents each (25\% each) suggested that for Ghana to enhance its conflict resistance capacities, there is the need for the country to redouble its peace education efforts, campaign for peace and unity, and increase security capacity, efficiency, and effectiveness to maintain law and order as well as suppress violence respectively. Good governance, economic growth, improvement of living standards, equitable distribution of economies of scale were suggested by 17 respondents (12.5\%), whilst tolerance and respect for others' views registered 12 responses $(9.4 \%)$. Some 8 respondents each $(6.3 \%$ each) suggested 
that politicians should not be involved in chieftaincy conflicts; the independent law courts should deal with conflict issue promptly; Ghanaians should avoid hate language in the media and the politics of insults in the country; and ensuring justice to all people of Ghana, respectively, will help to prevent large scale war.

Similarly, some 4 respondents each (3.1\% each) also suggested that Chieftaincy issues should be allowed to be handled by traditional leaders; no religion should be allowed to criticise another religion publicly; and the need to clamp down on corruption since corruption has the potential of creating violence in the country.

Table 9: Measures to Increase Ghana's Conflict Resilience Capacity

\begin{tabular}{|c|c|c|}
\hline \multicolumn{3}{|c|}{ Suggest measures that need to be taken to ensure Ghana increases her conflict resilience capacity. } \\
\hline Responses & Frequency & $\begin{array}{l}\text { Percentage } \\
\qquad(\%)\end{array}$ \\
\hline $\begin{array}{l}\text { Ensure that Ghana increases her conflict resilience capacity through peace } \\
\text { education, campaign for peace and unity }\end{array}$ & 33 & 25.0 \\
\hline $\begin{array}{l}\text { Increase security capacity, efficiency, and effectiveness to maintain law } \\
\text { and order as well as suppress violence }\end{array}$ & 33 & 25.0 \\
\hline $\begin{array}{l}\text { Good governance, economic growth, improvement of living standards, } \\
\text { equitable distribution of economies of scale }\end{array}$ & 17 & 12.5 \\
\hline Tolerance and respect for others views & 12 & 9.4 \\
\hline $\begin{array}{l}\text { Politicians should avoid meddling in chieftaincy conflicts and independent } \\
\text { law court should deal with chieftaincy issues promptly }\end{array}$ & 8 & 6.3 \\
\hline Avoid hate language in the media and the politics of insults in the country & 8 & 6.3 \\
\hline We must ensure justice to all people of Ghana & 8 & 6.3 \\
\hline Chieftaincy issues should be allowed to be handled by traditional leaders & 4 & 3.1 \\
\hline No religion should be allowed to criticise another religion publicly & 4 & 3.1 \\
\hline $\begin{array}{l}\text { Dealing swiftly with corruption to avoid any potential violent conflict in } \\
\text { the country }\end{array}$ & 4 & 3.1 \\
\hline Total & 132 & 100 \\
\hline
\end{tabular}

Source: Author's fieldwork, 2014/2015, Ghana.

\section{CONCLUSION}

This study concludes that Ghana fits into the theory of multiethnic, multi-cultural and pluralistic societies by dint of its diversity of cultures, many ethnic groups and diverse social cleavages. Ghana is also bedevilled with many internal conflicts as proven in the study data. However, on consociationalism as a concept of democratisation in plural societies, Ghana differs to a large extent because it does not have formally established democratic arrangements based on existing social cleavages as espoused by theories of consociationalism.

From the findings of this study, it could be suggested, that the success of democratisation in societies with multicultural cleavages and its sustainability do not only depend solely on formal consociational arrangements, but also, and more especially in Ghana, on the inherent non-formal 
arrangements and crosscutting ties that exist among the people across all divides and the disposition of the people to collaborate based on common interests imposed by these crosscutting ties that exist among the people. To this effect, we conclude that the concept of consociationalism, as this study proves, should be discussed with specific reference only to applicable contextual perspectives, and should be altered by weaving in the concept of crosscutting ties which, in the Ghanaian case, has overshadowed cleavage-based consociational arrangements. The emphasis on crosscutting ties in Ghana has succeeded because Ghana has formerly constitutionalised prohibitions to the institutionalisation of cleavage emphasis in the public space, thereby enhancing cross-cleavage relations, but not ignoring in-group alliances that, however, must not supersede the formal establishments that give emphasis to the national interest as enshrined in the constitution of Ghana.

\section{References}

Apter, D. (1972). Ghana in Transition. Princeton, New Jersey, Princeton University Press. 2nd Revised Edition, pp. 56-261.

Awedoba, A. K. et al (2009). An ethnographic study of Northern Ghanaian Conflicts: Towards a Sustainable Peace: Key Aspects of Past, Present and Impending Conflicts in Northern Ghana and Mechanisms for their Address. Sub-Saharan Publishers, Accra, Ghana. pp, 210-211.

Bercovitch, J. (1983). "Conflict and Conflict Management in Organizations: A Framework for Analysis”, The Asian Journal of Public Administration, 5(2), December, 1983.

Bogner, A. (2000). "The 1994 Civil War in Northern Ghana: The Genesis and Escalation of a 'Tribal Conflict. In Lentz, C. and Nugent, P. (eds.) Ethnicity in Ghana. The Limits of Invention. London Macmillan.

Bombande, E. (2007). "Conflicts, Civil Society Organisation in Northern Ghana.” In Tonah, S. (Ed) Bombande, E. (2007). “Conflicts, Civil Society Organisation in Northern Ghana.” In Tonah, S. (Ed). Ethnicity, Conflicts and Consensus in Ghana. (98-115). Accra, Ghana. Woeli Publishing Services.

Brukum, N. J. K. (1999). Chiefs, Colonial Policy and Politics in Northern Ghana, 1897-1956.

Brukum, N. J. K. (2006). Chieftaincy and Ethnic Conflicts in Northern Ghana, 1980-2002 In Irene k. Odotei and Albert K. Awedoba (Eds). Chieftaincy in Ghana: Culture, Governance and Development, Accra, Sub-Saharan Publishers. pp. 429-448.

Brukum, N. J. K. 1995. "Ethnic Conflicts in the Northern Region of Ghana: A Study of the Conflicts in the Gonja District: 1980-1994” In Oquaye, M. (ed.) Democracy and Conflict resolution in Ghana. Accra, Gold-Type Publications.

Citifmonline. "Konkombas, Dagombas clash again at Agbogbloshie; many injured". Tuesday, April 11, 2017 4:10 pm http://citifmonline.com/2017/04/11/konkombas-dagombas-clashagain-at-agbogbloshie-many-injured/ 
Coser, L. (1956). The Functions of Social Conflict. New York: The Free Press, 1956. pp. 78-79

Diamond, L. (2017). Democracy Only as Strong as Citizens' Support for It. SFGate. March 9, 2017. https://www.sfgate.com/opinion/article/Democracy-only-as-strong-as-citizenssupport-10991552.php

Drucker-Brown, (1995). "Communal Violence in Northern Ghana: Unacceptable Warfare" In Hinde R. A. and H. E Watson (eds.) War: A Cruel Necessity? The Basis of Institutionalised Violence. London Tauris.

Fisher, R., Ury, W., \& Patton, B. (1991). Getting to yes: Negotiating agreement without giving in.

Fred-Mensah, .K, (1999): “Capturing Ambiguities: Communal Conflict Management Alternative in Ghana". World Development Vol. 27. No. 6.

Galtung, J. (1969). Violence, Peace, and Peace Research. Journal of Peace Research, Vol. 6, No. 3 (1969), pp. 167-191. Sage Publications, Ltd.

Halpern, Sue M. (1984), Consociational democracy and the dangers of politics as science. Doctoral Study. Oxford: University of Oxford.

http://www.a1 radioonline.com/2017/08/17/tension-in-kumasi-as-abudus-andanis-clash-at-alabar/

Jurg Steiner (1971). "The Principles of Majority and Proportionality." British Journal of Political Science, 1, No. 1 (January 1971)65. Cited in Lijphart A. (1977). Democracy in Plural Societies: A Comparative Exploration. New Haven and London Yale University Press.

Kinsella, D. and Rousseau, D. L. (2009). Democracy and Conflict Resolution. In Bercovitch, J., Kremenyuk, V. and Zartman, I. W. (2009). SAGE Handbook of Conflict Resolution. SAGE UK, 2009.

Konate, Y. (2004). "The Question of Religion in Ivorian Crisis" In Goethe Institute (ed.) Conflict: What has Religion Got to Do with It? Accra, Woeli Publishing.

Lijphart, A. (1977). Politics in Plural Societies: A Comparative Exploration. New Haven and London Yale University Press. pp. 3-38

Lijphart, A. (1977). Politics in Plural Societies: A Comparative Exploration. New Haven and London Yale University Press. P.25.

Lijphart, A. (1977). Politics in Plural Societies: A Comparative Exploration. New Haven and London Yale University Press. p.37.

Lijphart, Arendt (1968b). 'Typologies of democratic systems'. Comparative Political Systems Vol. 1, No. 1, pp. 3-44.

Lijphart, Arendt (1969). "Consociational Democracy”. World Politics (October), Vol. 21, No. 1.Pp-207-25. USA: Princeton University Press.

Lijphart, Arendt (2000b). 'The wave of power-sharing democracy'. Cited in Noura, Assaf (2004). Consociational theory and democratic stability: A re-examination Case Study: Lebanon". Unpublished Study, University of Warwick, Department of Politics and International Studies 
Otite, O. 2000. Ethnic Pluralism, Ethnicity and Ethnic Conflicts in Nigeria. 2nd Ed. Ibadan: Shaneson C. I. Ltd.

Robin, D. (2002). When to engage, when not to engage. A Daniel Robin and Associates website. http://www.abetterworkplace.com

Thakore, D. (2013). Conflict and Conflict Management. IOSR Journal of Business and Management (IOSR-JBM) e-ISSN: 2278-487X. Volume 8, Issue 6 (Mar. - Apr. 2013), PP 07-16. www.iosrjournals.org

Tonah, S. (2007). Theoretical and Comparative Perspectives on Ethnicity, Conflicts and Consensus in Ghana. In Tonah, Steve (Ed). Ethnicity, Conflicts, Consensus in Ghana. pp. 3-24. Accra: Woeli Publishing Services

Tsikata, D. \& and Seini, W. (2004). Identities, Inequalities \& Conflicts in Ghana. Working Paper 4.

Tsikata, D. \& Seini, W. (2004). Identities, Inequalities and Conflicts in Ghana. CRISE Working Paper 5, November 2004. Queen Elizabeth House, University of Oxford. p.29Bell, A. (2002). Six Ways to Resolve Workplace Conflicts. San Francisco, CA: University of San Francisco.

Van Shendelen M. P. C .M (1984). 'The views of Arendt Lijphart and collected criticisms. In Van Schendelen, ed. Acta Politica Vol. 19, No. 1 [Consociationalism, pillarisation, \& conflict management in the Low Countries], (January), pp. 19-55. Amsterdam: U itgeverij Boom

Verma, V. K. (1998). Conflict Management. In Pinto, J. (Ed) (1998). The Project Management Institute Project Management Handbook 1998 ISBN 0-7879-4013-5.

Wallensteen, P. (2007). Understanding Conflict Resolution: War, Peace and the Global System. SAGE Publications, 2007

Yousef, S., Hipel, K. W., \& Hegazy, T. (2010). Attitude-based strategic negotiation for conflict management in construction projects. Paper presented at PMI Research Conference: Defining the Future of Project Management, Washington, DC. Newtown Square, PA: Project Management Institute. Found online at https://www.pmi.org/learning/library/attitude-based-strategic-negotiation-conflict-6476

Zeytoonian, M (2014). Lessons from Jerusalem; Part I: what attitude do we bring to our conflicts?, Dispute Resolution Council, LLC, September 18, 2014 